\title{
From the application of active teaching methods to significant learning in Cellular and Molecular Biology: exploring possibilities with Problem Based Learning
}

\author{
Da aplicação de metodologias ativas à aprendizagem significativa em Biologia Celular e Molecular: \\ explorando possibilidades com Aprendizagem Baseada em Problemas
}

\author{
Giulian César da Silva Sá ${ }^{1,2^{*}}$, Leidiane Barboza da Silva ${ }^{1,2}$, Elizeu Antunes dos Santos ${ }^{1}$, Adriana Ferreira Uchôa ${ }^{1,2}$ \\ ${ }^{1}$ Programa de Pós-Graduação em Bioquímica e Biologia Molecular, Universidade Federal do Rio Grande do Norte \\ (UFRN), campus Natal-RN, Brazil. \\ ${ }^{2}$ Instituto de Medicina Tropical do Rio Grande do Norte (IMT), Natal-RN, Brazil. \\ *e-mail: giuliancesarsa@gmail.com
}

Support: Coordenação de Aperfeiçoamento de Pessoal de Nível Superior (CAPES, Brazil) and Conselho Nacional de Desenvolvimento Científico e Tecnológico (CNPq, Brazil)

\begin{abstract}
Cellular and Molecular Biology contents are discussed in high school integrated to discipline Biology. However, the success of these reflections in higher education is compromised by the unavailability or restriction of the application of active teaching methods, because the students have little familiarity with terms used and these contents are not yet fully discussed, aiming at significant learning. This Teaching Research was the result of a graduate teaching practice and explored the possibility that Problem-Based Learning (PBL) facilitates the significant acquisition of themes in Cellular and Molecular Biology by students from a public institution of higher education in northeastern Brazil. This graduate teaching practice provided to graduate student the opportunity to experience, learn and test innovative teaching and research techniques, and to build new skills. After PBL employment, students acquired competences that would probably not be developed in other common activities with the same effectiveness, and students with learning difficulties in Cellular and Molecular Biology contents or in relationships with their classmates have improved their performance and affectivity. Thus, we suggest the PBL as a pedagogical support to teaching practice, for contributing to making students active in the teaching-learning process and improve the perception of the concreteness of the studied knowledge.
\end{abstract}

Keywords: Problem Based Learning; Significant Learning; Active Teaching Methods.

\section{Resumo}

Os conteúdos de Biologia Celular e Molecular são discutidos no ensino médio integrados à disciplina Biologia. Entretanto, o sucesso dessas reflexões no ensino superior é comprometido pela indisponibilidade ou restrição da aplicação de metodologias ativas, pela pouca familiaridade com os termos utilizados e por não serem discutidos visando a aprendizagem significativa. Esta Pesquisa de Ensino foi resultado de uma prática de docência da pósgraduação e explorou a possibilidade de a Aprendizagem Baseada em Problemas (ABP) facilitar a aquisição significativa de temas em Biologia Celular e Molecular por estudantes de uma instituição pública de ensino superior do Nordeste brasileiro. Essa experiência de docência assistida proporcionou aos pós-graduandos a oportunidade de vivenciar, aprender e testar métodos inovadores de ensino e pesquisa, além de desenvolver novas habilidades. Após o emprego da ABP, os estudantes adquiriram competências que provavelmente não seriam desenvolvidas em outras atividades convencionais com a mesma eficácia, e aqueles com dificuldades de assimilar conteúdos de Biologia Celular e Molecular ou de estabelecer relações interpessoais com seus colegas de classe ampliaram seu desempenho e afetividade. Assim, apontamos a ABP como suporte pedagógico à prática docente, por tornar os estudantes atuantes no processo de ensino-aprendizagem e aprimorar a percepção da concretude do conhecimento estudado.

Palavras-chave: Aprendizagem Baseada em Problemas; Aprendizagem Significativa; Metodologias Ativas. 


\section{Record activity performed}

\begin{tabular}{|c|c|}
\hline Title & $\begin{array}{l}\text { From the application of active teaching methods to significant learning in Cellular } \\
\text { and Molecular Biology: exploring possibilities with Problem Based Learning }\end{array}$ \\
\hline $\begin{array}{l}\text { Target } \\
\text { audience }\end{array}$ & Undergraduate Students \\
\hline $\begin{array}{l}\text { Related } \\
\text { disciplines }\end{array}$ & Cellular and Molecular Biology \\
\hline $\begin{array}{l}\text { Educational } \\
\text { objectives }\end{array}$ & $\begin{array}{l}\text { Recognizing the importance of active teaching methods in promoting of } \\
\text { significative learning, this Teaching Research, result of a graduate teaching } \\
\text { practice, aimed to explore the possibility that Problem Based Learning (PBL) } \\
\text { facilitates the significant acquisition of themes in Cellular and Molecular Biology } \\
\text { in Nutrition course students from a public institution of higher education } \\
\text { (Northeastern, Brazil). }\end{array}$ \\
\hline $\begin{array}{l}\text { Justification of } \\
\text { use }\end{array}$ & $\begin{array}{l}\text { In higher education, the courses disciplines in the health areas demand a } \\
\text { constant updating of its management in the perspective of contemplating the } \\
\text { new discoveries that usually occur during the contents teaching. A strategy that } \\
\text { has been used in order to facilitate the teaching and learning process, is through } \\
\text { the use of active methodologies, such as PBL. PBL is a strategy designed to } \\
\text { improve learning, requiring students to acquire skills and knowledge while } \\
\text { solving the proposed problem, developing active learning. Thus, we suggest the } \\
\text { PBL as a pedagogical support to teaching practice, making students responsible } \\
\text { for the teaching-learning process. }\end{array}$ \\
\hline $\begin{array}{l}\text { Worked } \\
\text { contents }\end{array}$ & $\begin{array}{l}\text { 1) Biological membranes: general presentation; } \\
\text { 2) Lipid bilayer: general characteristics, membrane lipids, phospholipids and the } \\
\text { formation of bilayers, two-dimensionality and asymmetry, and fluidity and lipid } \\
\text { membrane domains; } \\
\text { 3) Membrane proteins: general classification and glycosylation; } \\
\text { 4) Membrane specializations; } \\
\text { 5) Membrane transport: biological importance, class of proteins involved in } \\
\text { transport and types of transport; and } \\
\text { 6) lon channels and electrical properties of membranes: general characteristics, } \\
\text { biological activity of ion channels and aquaporins. }\end{array}$ \\
\hline $\begin{array}{l}\text { Estimated } \\
\text { duration }\end{array}$ & $\begin{array}{l}\text { PBL consisted of the execution cycle, which is applied in three phases: } \\
\text { 1) a phase of presentation and analysis of problem-situations to students ( } 45 \\
\text { minutes); } \\
\text { 2) a self-directed learning phase, where students will plan and analyze their } \\
\text { investigations in search of possible solutions to the problems presented ( } 72 \\
\text { hours); and } \\
\text { 3) a phase of synthesis and reporting, where the groups will demonstrate their } \\
\text { learning, from the perspective of reflecting on the proposed problem ( } 40 \text { minutes } \\
\text { for reading the problem-text and defining the items and objectives for discussion, } \\
35 \text { minutes for problematizing the objectives, and } 20 \text { minutes for theoretical } \\
\text { group discussion and assembly of a mind map with the deliberations). }\end{array}$ \\
\hline Materials used & Power Point software, paper and pens. \\
\hline
\end{tabular}




\section{Introduction}

Failures in the transmission of elementary contents are observed in the educational scenario, which are disseminated decontextualized and mechanically, disregarding the student's reality, experience and his previous knowledge [1]. These failures accompany the student from basic education to higher education, where the biology contents are not transmitted in the perspective of expanding the understanding possibilities and effective participation of students in the current world. Thus, the educational scenario is characterized by the notorious content accumulation and the predominance of methodologies purely expository, limiting the subject-object interaction and increasing the probability of not achieving significant learning [2,3,4].

Cellular and Molecular Biology contents are discussed in high school integrated to discipline Biology, serving as a basis for understanding other areas of biological knowledge [5,6] and enabling students to expand their world knowledge and understanding of life phenomena [2,7]. The success of these reflections is compromised by the unavailability or resources restriction that enhance their effectiveness [8], because the students have little familiarity with terms used [9] and by the lack of connection between the advances in Contemporary Biology with school curricula $[3,4,10]$.

In higher education, the disciplines of health courses demand a constant updating of its management, in the perspective of contemplating the new discoveries that usually occur during the contents teaching. However, the lack of educational reforms that assist these demands strengthens cases of failure due it does not include the adoption of significant teaching and learning methods [11,12]. Perhaps the reason for the usual and high rates of this failure is that the teaching-learning process occurs - most of the time, by memorization and in an arbitrary and literal way, turning the students not able to learn new meanings. However, when education is designed to promote constant interactions between new knowledge and student's cognitive structure, it is expected that learning will be of higher quality and, consequently, significant [13].

Cellular and Molecular Biology is a discipline of numerous undergraduate courses, and has a high interdisciplinary and complex character in addition to the limited workload and the increase of incorporated content, encouraging the teacher to employ strategies that value for the systematization and meaning of the contents to the students. However, many teachers are not motivated to employ these strategies, opting for more conventional ones. An alternative to repair this problem is the use of active teaching methods. These methods are incorporated into the school routine and make the student the protagonist of 
the teaching-learning process, the teacher is recognized as a tutor in the knowledge construction, and teaching institutions and moments in the classroom become appropriate sources of scientifically based information transmission $[13,14,15]$.

Active methodologies have been used in healthcare courses since 1969, at McMaster University in Canada. In Brazil, the first report was from 1997 and include several approaches [15]. Among them, Problem Based Learning (PBL), an approach that has been used in many curricula around the world for more than 50 years and aims to promote communication skills, collaboration, decision making, resolution problems, critical thinking and self-directed learning [16]. The PBL learning experience invites students to organize how learning will be achieved, supported by a tutor/facilitator in managing shared information [17]. Although its implementation varies in different contexts, in general, PBL use relevant problems as motivators and guides of the execution cycle, which is applied in three phases: 1) presentation and analysis of problem-situations to students, that they will organize themselves in groups to debate them; 2) a self-directed learning phase, where students will plan and analyze their investigations in search of possible solutions to the problems presented; and 3) synthesis and reporting phase, where the groups will demonstrate their learning, from the perspective of reflecting on the proposed problem. All progress is monitored by the teacher and the students themselves, as problematizations are induced $[16,18]$.

Recognizing the importance of active methodologies in promoting significant learning, this Teaching Research aimed to explore the possibility that PBL facilitates the significant acquisition of themes related to Cellular and Molecular Biology for Nutrition course students from Universidade Federal do Rio Grande do Norte (UFRN), a public institution from Northeastern of Brazil (Natal, Rio Grande do Norte). This research was result of a graduate teaching practice, a mandatory activity for scholarships from Graduate Program in Biochemistry and Molecular Biology of UFRN.

\section{Methodological Design}

This is phenomenological research [19] with mixed approach [20, 21]. The case study was chosen as methodological strategy [22] and its target audience included Nutrition course students from UFRN, registered in the curriculum components of Cellular and Molecular Biology. We planned this research considering four aspects, according to Santos et al. [23]: i) time distribution (data were collected sequentially, consisting of an initial quantitative phase followed by a qualitative phase); ii) weight assignment (weight 
was evenly distributed to data from the two approaches from item i); iii) the combination (occurred by incorporation, in the perspective of a sequential transformative research); and iv) theorizing (it occurred through the application of the active methodology, PBL, would expand students' knowledge about the problems worked on).

\subsection{Data collect}

The data were collected and organized in three interrelated stages. The first stage consisted of the non-interventional observation of classes in the aforementioned curriculum components, aiming to understand its emerging demands and necessary strategies to apply the proposed methodology. After follow-up of classes, the students received a questionnaire containing basic level discursive questions (open-ended) about the physiology and dynamism of biological membranes, taking the second stage. The questionnaires remained with the students throughout the research. Initially, students should answer questions without consultation and after each pedagogical intervention, students were asked to re-evaluate their answers indicating the progress/correction with pens of different ink colors. The purpose of this stage was to encourage students to scientifically assess and develop their knowledge. The questionnaires were organized into six categories, containing questions specific to each category, as shown below:

\section{1) Biological membranes: general presentation;}

- Define biological membranes, pointing out its general characteristics.

- Point out the main constituents of biological membranes.

2) Lipid bilayer: general characteristics, membrane lipids, phospholipids and the formation of bilayers, two-dimensionality and asymmetry, and fluidity and lipid membrane domains;

- Comment on the importance of lipids in the bilayer constitution of biological membranes, pointing out which lipid class is most abundant.

- What is the biological importance of the two-dimensionality and asymmetry of the lipid bilayers?

3) Membrane proteins: general classification and glycosylation;

- How are membrane proteins classified and what its importance in the constitution of biological membranes?

- Comment on the glycosylation of membrane proteins.

4) Membrane specializations;

- Comment on the specializations of biological membranes. 
5) Membrane transport: biological importance, class of proteins involved in transport and types of transport;

- What classes of proteins are involved in membrane transports and how do its work?

- What are the types of membrane transport (point out its differences)?

6) Ion channels and electrical properties of membranes: general characteristics, biological activity of ion channels and aquaporins.

- What is the difference between ion channels and carrier proteins?

- Comment on the electrical properties of membranes (emphasizing the membrane action potential) and intracellular osmolarity (pointing out the difference in osmotic control of animal, plant and protozoan cells).

In the third and last stage, a PBL approach was developed. In order to make the methodology more attractive to students, it was proposed a PBL based on Harry Potter trilogy, by British writer JK Rowling, which narrates the adventures of a teenager who discovers, at the age of 11 , that he is a famous wizard at be invited to study at the Hogwarts School of Witchcraft and Wizardry. Below, we present the basic text of the PBL:

Dear Mr. Alastor Moody (in memoriam), Honorable Auror of this Magic Ministry

Because of his also honorable ability to employ offensive and defensive magic, personally surrendering to him the filling of Azkaban's cells with Death Eaters, I, Mrs. Hermione Jean Weasley, Minister of Magic, invite you to solve another problem relating to the dark arts. In advance, I apologize for the informality.

I find myself very distressed because of the numerous requests for support I have been receiving. The first came from Mr. Neville Longbottom, professor of Herbology at Hogwarts School of Witchcraft and Magic, who has long questioned that "strange actions" have been taking place in his classes. In one of their outbursts, he claims that "First-year students usually (teacher laughs) come to question me about biological membranes, lipids, proteins, glycosylation, membrane potential and how it affects the functioning of the material (plants... ooohh plants... I love plants) I use in my classes. Mrs. Minister, I'm going crazy. So... how can I intervene in these questions and help these students?" 
Well, dear friend Moody (if I may consider it) ... Professor Longbottom was not the only one to lodge complaints with the Ministry. Next to this, I remember that professors Igor Karkaroff, Director of the Durmstrang Institute of Witchcraft, and Madame Maxime, director of the Beauxbatons Academy of Magic, while at Hogwarts for the Triwizard Tournament (in 1994), presented severe criticism to Professor Dumbledore when Harry Potter was chosen by the Goblet of Fire. According to them, Potter violated the hall of general characteristics expected to the lipid bilayers of membranes or, with the help of You-Know-Who (please do not pronounce his name, even if Harry having defeated him), interfered in the conquest of the Triwizard Tournament by the champions of their schools, Vítor Krum and Fleur Isabelle Delacour Weasley, respectively.

Professor Karkaroff's accounts are the most striking, in his words: "Minister, this is absurd. My student (true champion of the Triwizard Tournament), Vitor Krum, in his first task faced the Chinese Fireball dragon. Knowing that the dragons' eyes are sensitive, he used the spell 'Conjuntivictus' to catch the dragon's egg, but lost some points because when he cast the spell on the dragon, Krum (idiot) stepped on the other eggs. The question is: why such injustice, Minister? To conjure this spell, he had to understand the biogenesis, two-dimensionality, asymmetry and fluidity of lipid bilayers, in addition to the general characteristics of lipids and membrane lipid domains. Why didn't he win? Did he miss something? Tell me what you think is incorrect."

Finally, as if I wasn't enough, Divination teacher, Sybill Trelawney (crazy, my griffin), continues to predict a horrible death for Harry Potter at least once every class. You may remember, but she was almost expelled from school by Dolores Umbridge. Unfortunately, in 1995 by order of the Ministry, she was installed as the Defense Against the Dark Arts Professor at Hogwarts and then later the Hogwarts High Inquisitor and Headmistress of Hogwarts, after Professor Dumbledore had been fired (you must agree with me that choice was horrible). Well, Professor Trelawney remains reclusive at the top of the north tower, not to lose the clairvoyant, according to her (foolishness, I would say).

These days, I receive, in my office, Professor Trelawney and she tells me (screams, indeed) this: "Minister, I know that you do not have the gift of clairvoyant, but you must remember that I warned you when the one with the power to defeat the Dark Lord would approach and the Dark Lord will mark him as his equal, but he will have power the Dark Lord knows not ... and either must 
die at the hand of the other for neither can live while the other survives... The only thing I didn't warn you about is that all this was due to the pro... pro... membrane proteins and i... i... ionic... cha... cha... channels ooohh... membrane proteins and ionic channels and their performance in membrane transports." I was horrified and almost set her in a saddle with a Troglodytarum alpinum (adult), but I took a deep breath and resonated; it was hard, but I controlled myself. Not to mention the horrible herbs odor she left in my room.

Dear friend Alastor Moody, please help me understand what our wizarding friends are trying to tell me. I'm already beginning to believe that the Dark Lord is alive and that he's influencing the minds of these teachers. When possible, come visit us. I forgot to tell you, Ron and me are fine.

Best regards,

\section{Hermione Jean Weasley}

Minister of Magic.

Summer 2020, British Ministry of Magic.

\subsection{About the PBL development}

The PBL proposed in this research involving the six themes presented above (see topic 2.1). In the first session, it includes the presentation and analysis phase of problemsituations to students, and a self-directed learning phase. The clarification of unknown terms was carried out through classroom debates mediated by theoretical exhibitions, as well as the definition of the problem core and learning objectives, being considered and problematized all the previous knowledge of the students.

The second session was initiated with synthesis and reporting, and closure and resolution of the proposed problem-situations. In this session, students were invited to consult (during the 72-hour interval between sessions) on the subject and discuss the proposed problems in groups. The students were organized into four groups of six students (we suggest that groups do not exceed this number, avoiding compromising discussions). Each group had a rapporteur to record the group's decisions and results, and a coordinator, responsible for managing time and discussions. The execution was chronologically organized as follows: 40 minutes to read the problem text and definition of items and objectives for discussion, 35 minutes for objectives problematization and theoretical discussion in group, and 20 minutes for the construction of a mind map containing the group's deliberations. Finally, each group, represented by its rapporteur, 
presented its items and objectives for discussion through the mind maps, enabling different interpretations of the same problem (physiology and dynamism of biological membranes). After the presentation of mind maps, there were debates that allowed the students to reorganize the learning objectives and investigate the physiology and dynamism of biological membranes from different perspectives.

By affinity, the groups were free to present a solution to one or all of the problems presented throughout the text proposed. At the end of all interventions, data systematization and analysis of the response's improvement occurred that students prescribed in the questionnaires (emergence of scientific terms and more informative elements on the issues discussed, and the capacity for self-criticism in your previous answers). We emphasize that characteristics such as color/race, ethnicity, sexual orientation and gender identity were not relevant for the research, and that all participants received a signed copy of a Free and Informed Consent Form, according to recommendations of the National Ethics Commission in Research from the Brazilian Ministry of Health.

\subsection{Data analyses}

At the end of interventions, the students returned the questionnaires whose answers were corrected by themselves, using as parameter the knowledge acquired/enhanced through interventions and autonomous research. Initially, it was suggested that the students answered the questionnaires using pens in blue or black colors, and as interventions occurred, the answers were corrected using different ink colors. The questionnaires analysis was conducted under two parameters: 1) questions answered unsatisfactorily, considering answers like "I don't know" or "I don't remember", scribbles in the answer fields, information that does not match the question asked and/or questions with no answer; and 2) questions answered satisfactorily, considering answers consistent with the statement. The progress of answers was analyzed from the proposed color system, compared with the evolution presented to each correction made by the students and categorized according to the Isacson \& Bingefors method [24], considering three levels of knowledge: low (score from 0 to 3 ), for the questions answered unsatisfactory; and moderate (score from 4 to 6) or high (score from 7 to 10), for questions answered satisfactorily. 


\section{Results and Discussions}

\subsection{Relevance of the graduate teaching practice}

The experiences provided by the graduate teaching practice allowed the graduate students to assume a safe posture about their work as a future education professional, especially on the use of significant methodological approaches. Our result corroborates with Fonseca \& Pereira [27], when they show that the graduate student tends to take the internship with responsibly. Additionally, the graduate students, in their pedagogical practice in assisted teaching, encouraged the students of Nutrition course to discuss problems of their daily life and future profession, through the appropriation of contents in Cellular and Molecular Biology. The success of these results was due to the collaborative work of the graduate students and their teacher advisors (according to Graduate Program in Biochemistry and Molecular Biology standards, UFRN, the graduate students need to be supervised by a professor, preferably their advisors), aiming at the reflection of the most significant practices to be developed during the graduate teaching practice. Thus, we reinforce the importance of a good relationship between the graduate students and their teacher advisors.

The graduate teaching practice induce significant discussions that enable graduate students to think about social issues and the parameters for their professional training. Being a teacher, in this context, requires the understanding that teaching is a practice of social intervention and the teacher has the opportunity to reorganize knowledge and pedagogical experience, giving them application and legitimacy [25]. Amaral-Filho et al. [26] also state that the opportunity to take the graduate teaching practice allows graduate students to expand their theoretical frameworks, contextualizing them with historicalcultural aspects, and to build new skills. In Brazil, the Ordinance n. 76/2010 of the Coordenação de Aperfeiçoamento de Pessoal de Nível Superior - CAPES (loose translation, Coordination for the Improvement of Higher Education Personnel), article 18, considers that the graduate teaching practice is an integral part of the graduate students, aiming at the preparation for teaching and the qualification of higher education [25].

The graduate teaching practice also provided opportunities for the development and improvement of competencies in graduate students, such as: to develop classes more meaningful and dynamic; to learn innovative teaching techniques and methods, contributing to complement academic training; to test teaching and research practices; and to build new skills and complement the theoretical learning of your curriculum. Thus, it is 
evident that the graduate teaching practice reduced the distance between theory and practice and provided the experience of being in contact with the higher education, as a teacher.

\subsection{Contributions of teaching practice and application of PBL}

After follow-up of classes, the students of Nutrition course from UFRN received a questionnaire containing discursive questions (open-ended) about the physiology and dynamism of biological membranes. Figure 1 shows the evolution of the answers provided in the questionnaires, analyzed according to color system proposed in topic 2.1. The improvement in responses was evident due to the increase in the number of questions answered satisfactorily. Before the interventions (understood here as first application), the students' knowledge ranged mostly from low $(52.27 \%$ of responses) and moderate (33.33\% of responses), according to Isacson \& Bingefors [24] method. However, after the interventions (understood here as second application), this profile changes and oscillates between high (52.65\% of responses) and moderate (35.61\% of responses). We highlight that the goal was not to present purely quantitative data to the students, but to make them reflect on the conceptual evolution for the themes addressed.

Figure 1. Student knowledge levels based on answers provided in the questionnaires.

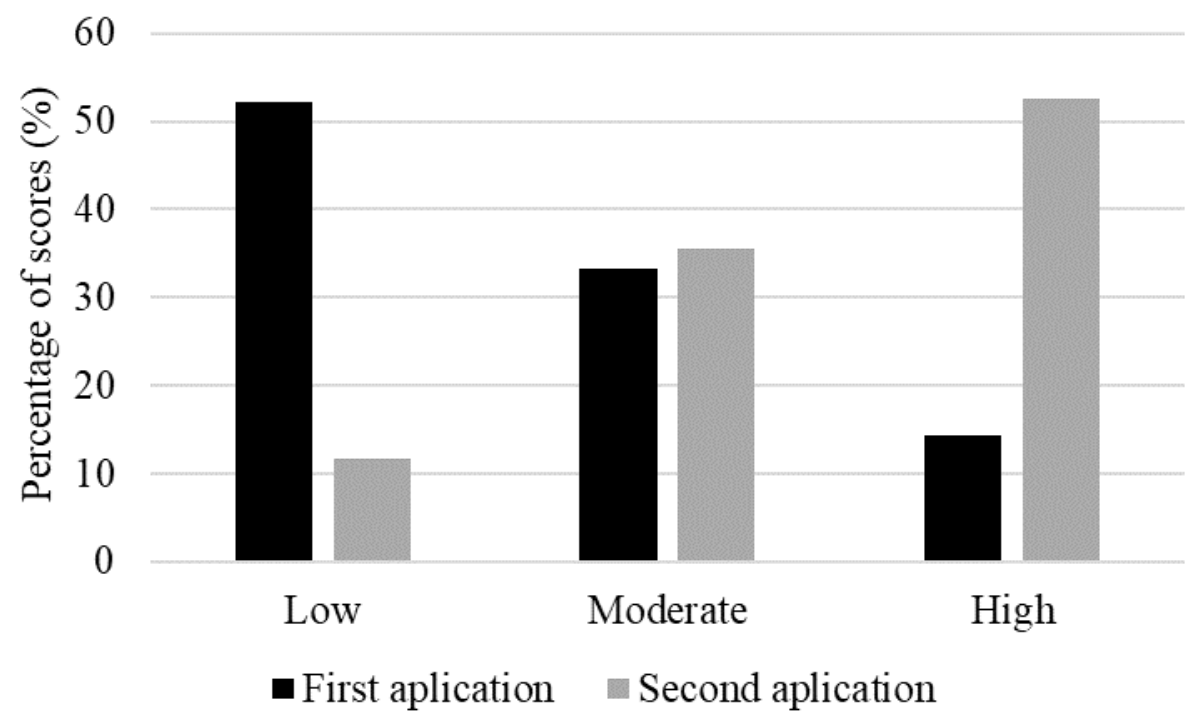

The answers provided in the questionnaires showed that students arrive at higher education with weaknesses in Cellular and Molecular Biology contents, perhaps due to the little maturation of these contents, to weaknesses in socialization processes or the little 
interest in answering the questions from questionnaire. Thus, we highlight the need to implement approaches capable of making these concepts more concrete and meaningful to students since the beginning of their academic journey, in addition to offering strategies to boost its execution. These results also suggest the importance of PBL in improving these (student knowledge levels) and other indexes, because PBL allows students to collectively investigate and solve the proposed problems, thus building their knowledge. Our results corroborate with Masitoh \& Fitriyani [18] on PBL enable a learning approach that uses problems inserted in a contemporary and attractive context for students, allowing them to learn how to use their problem-solving skills through motivating, challenging and fun perspectives. Perform a PBL on the Harry Potter theme was a strategy that enabled the acceptance of $100 \%$ of students, because they (in formal reports collected during execution) had fun learning.

We chose not to apply any instrument to quantify the development of cognitive skills compared to other methodological strategies. However, from the dynamic explanation of the contents through the PBL execution, the students were able to develop criticality and evaluate their knowledge about the contents addressed, corroborating Tudor Car et al. [16] and Aragon et al. [17] on the potential of PBL in improving cognitive skills. Unlike the methods traditionally used in Cellular and Molecular Biology classes, the PBL can also enhance the critical reflection of learning, besides allowing the teacher to take responsibility for the adaptation to the new reality experienced by the students. In addition to helping graduate students to be critical with their professional practice.

During the group socialization phase, students began to interact better and listen/respect the opinion of colleagues and this, consequently, may have helped to overcome learning difficulties and improved academic performance. Lovato et al. [28] emphasize that the use of more dynamic teaching strategies allows for greater knowledgeteacher-student interaction, bringing contributions to the teaching-learning process. This reinforces the importance of $\mathrm{PBL}$ in several aspects that directly and indirectly influence student learning. According to the Theory of Multiple Intelligences, proposed by Gardner \& Veronese [29], the teacher should consider the ability to solve problems and develop products that are important in a given environment or cultural community. Thus, it is suggested the application of PBL, mainly in Cellular and Molecular Biology classes, by allowing students to learn in different ways, leaving professors and graduate students to discover teaching-learning strategies that contribute to the development of their skills. 


\section{Final Considerations}

The ability to understand, build and expose concepts and ideas accompanies human beings from the first stages of their academic education and is inherent to human nature. The discussion of this experiences is indispensable for structuring and disseminating academic/scientific knowledge. However, most students and teachers do not understand this perception, requiring a new meaning in teaching. Among countless possibilities, we suggest the application of the active teaching methods to improve teaching in Cellular and Molecular Biology, making students protagonists of the teachinglearning process, through a transformative perspective.

The first stage of the adopted strategy was essential for the recognition of research universe, obtaining the students' conceptual weaknesses on physiology and dynamism of biological membranes. The results obtained from conducting the PBL highlighted the importance of reflecting on the meaning that Cellular and Molecular Biology contents should have for students. Thus, the objectives achievement was possible through the offer of new possibilities to interpret the problems and significant strategies to use Cellular and Molecular Biology contents; in addition to considering criticisms about recurrent problems, from discussions in the classroom. We believe that alternative pedagogical practices, such as PBL, expand paths that lead students to understand the most diverse mechanisms of life and to recognize themselves as part of the process. However, it is not the intention of this research to suggest that lectures should be abolished, or to belittle their success. Here, we point out the PBL as a pedagogical support to teaching practice, recognizing in students the previous knowledge, their responsibility and a proactive role in the teachinglearning process.

\section{References}

[1] Pessoa FB, Maki CS, Fialho MCQ. Estratégias pedagógicas para o ensino de Citologia e Histologia para alunos do ensino médio. Revista Ciência em Extensão. 2018;14(2):138-146.

[2] Martins G, Galego LGC, Araújo CHM. Análise da produção de vídeos didáticos de Biologia Celular em stop motion com base na Teoria Cognitiva de Aprendizagem Multimídia. Revista Brasileira de Ensino de Ciência e Tecnologia. 2017;10(3):185-205.

[3] Costa JM. Software interativo como ferramenta para a otimização do ensino de Biologia Celular [mestrado]. Universidade Tecnológica Federal do Paraná; 2017.

[4] Bonzanini TK. Avanços recentes em Biologia Celular e Molecular, questões éticas envolvidas e sua abordagem em aulas de Biologia no ensino médio: um estudo de caso [Mestrado]. Faculdade de Ciências; 2005.

[5] Leão GMC. Diferentes estratégias metodológicas para o processo de ensino e aprendizagem da Biologia Celular [Doutorado]. Universidade Federal do Paraná; 2018. 
[6] Santos JS, Cortelazzo AL. Os conteúdos de Biologia Celular no Exame Nacional do Ensino Médio ENEM. Avaliação, 2013;18(3):591-612.

[7] Santos JS. Avaliação dos conteúdos de Biologia Celular no Ensino Médio: estudos de caso sobre a prática docente e sua relação com exames de ingresso no ensino superior [Mestrado]. Universidade Estadual de Campinas; 2008.

[8] Glaser V, Pierre PMO, Fioreze ACCL. Teaching-learning strategies as alternative to teach Cell Biology: continuing education for High Schools teachers in Curitibanos-SC. Journal of Biochemisry Education. 2017;15(2):49-74.

[9] Legey AP, Jurberg C, Coutinho CMLM. Educação científica na mídia impressa brasileira: avaliação da divulgação de Biologia Celular em jornais e revistas selecionados. Revista de Educação em Ciência e Tecnologia. 2009;2(3):35-52.

[10] Justina LAD, Ferla MR. A utilização de modelos didáticos no ensino de Genética - exemplo de representação de compactação do DNA eucarioto. Arquivos do Mudi. 2006;10(2):35-40.

[11] Souza-Júnior AA, Andrade GPV, Santos EA. Ensino híbrido e gamificação aplicado no ensino de Bioquímica. Revista de Ensino de Bioquímica. 2019;16(2):87-103.

[12] Mesquita SKC, Meneses RMV, Ramos DKR. Metodologias ativas de ensino/aprendizagem: dificuldades de docentes em curso de Enfermagem. Trabalho, Educação e Saúde. 2016;4(2):473-486.

[13] Andrade V, Staudt K, Moerschbacher S, Ajala E, Fiorin T, Santos A, Lawall, I. Análise do conhecimento dos acadêmicos das áreas biológicas e saúde sobre o dogma "DNA - RNA - Proteína". Revista de Ensino de Bioquímica. 2019;17(1):1-15.

[14] Costa C, Galembeck E. Novel study guides for biochemistry meaningful learning in biology: a designbased research. Revista de Ensino de Bioquímica. 2017;15(2):75-113.

[15] Freitas CM, Freitas CASL, Parente JRF, Vasconcelos MIO, Lima GK, Mesquita KO, Martins SC, Mendes JDR. Uso de metodologias ativas de aprendizagem para a educação na saúde: análise da produção científica. Trabalho, Educação e Saúde. 2015;13(Suppl. 2):117-130.

[16] Tudor Car L, Kyaw BM, Dunleavy G, Smart NA, Semwal M, Rotgans JI, Low-Beer N, Campbell J. Digital Problem-Based Learning in health professions: systematic review and meta-analysis by the digital health education collaboration. Journal of Medical Internet Research. 2019;21(2):1-12.

[17] Aragão JA, Freire MM, Nolasco Farias LG, Diniz SS, Sant'anna Aragão FM, Sant'anna Aragão IC, Lima TB, Reis FP. Prevalence of depressive symptoms among medical students taught using problem-based learning versus traditional methods. International Journal of Psychiatry in Clinical Practice. 2017;22(2):123128.

[18] Masitoh LF, Fitriyani H. Improving students' mathematics self-efficacy through problem-based learning. Malikussaleh Journal of Mathematics Learning. 2018;1(1):26-30.

[19] Sato M. Apaixonadamente pesquisadora em Educação Ambiental. Educação. Revista Teoria e Prática. 2001;9(16):24-35.

[20] Neves JL. Pesquisa qualitativa - características, usos e possibilidades. Caderno de Pesquisas em Administração. 1996;1(3):1-5.

[21] Marconi MA, Lakatos EM. Fundamentos de Metodologia Científica. 7. ed. São Paulo: Atlas; 2010.

[22] Yin RK. Estudo de Caso: planejamento e métodos. 3. ed. Porto Alegre: Bookman; 2005.

[23] Santos JLG, Erdmann AL, Meirelles BHS, Lanzoni GMM, Cunha VP, Ross R. Integração entre dados quantitativos e qualitativos em uma pesquisa de métodos mistos. Texto \& Contexto Enfermagem. 2017;26(3):1-9. 
[24] Isacson D, Bingefors K. Attitudes towards drugs - a survey in the general population. Pharmacy World and Science. 2002;24(3):104-110.

[25] Ribeiro MFBS. Formação pedagógica nos Programas de Pós-graduação Stricto Sensu da UNIOESTE/Campus Cascavel-PR: um estudo sobre o estágio de docência [mestrado]. Universidade Estadual do Oeste do Paraná; 2019.

[26] Amaral-Filho FS, Veiga AA, Gebert AB, Romaniuk C. Estágio Docência: uma atividade do Programa de Pós-graduação em Educação da Universidade Tuiuti do Paraná. Revista Tuiuti: Ciência e Cultura. 2019;6(59):131-145.

[27] Fonseca CV, Pereira CLZ. Chemistry Teaching Internship: proposition of problem- situations involving inorganic chemistry. Brazilian Journal of Education, Technology and Society. 2019;12(4):362-372.

[28] Lovato F, Christo T, Pagliarini D, Costa F, Bartholomei-Santos M. Na trilha dos genes: uma proposta de jogo didático para o ensino de Genética. Revista de Ensino de Bioquímica. 2018;16(2):5-30.

[29] Gardner H, Veronese MAV. Inteligências múltiplas: a teoria na prática. 1. ed. Porto Alegre: Artes Médicas; 1995.

\section{Acknowledgments}

The authors thank the Coordenação de Aperfeiçoamento de Pessoal de Nível Superior (CAPES, Brazil) for the financial support and the scholarship granted to the first author; also, the Ministério da Ciência, Tecnologia e Inovações (MCTIC, Brazil) and the Conselho Nacional de Desenvolvimento Científico e Tecnológico (CNPq, Brazil) for the financial support to the laboratories and researchers involved. G.C.S.S. and L.B.S. received a scholarship from CAPES. 